\title{
The Influence of Principal Servant Leadership, Self-Efficacy and Teacher Work Involvement on Organizational Citizenship Behavior (OCB) in Improving Teacher Work Performance at the Yayasan Abdi Karya Elementary Education Level
}

\author{
Meilani $^{1}$, Setyo Riyanto ${ }^{2}$ \\ ${ }^{1}$ Master of Management Program Student, Universitas Mercu Buana, Jakarta, Indonesia \\ ${ }^{2}$ Associates Professor, Universitas Mercu Buana, Jakarta, Indonesia
}

\begin{abstract}
This study aims to analyze the influence of the principal's servant leadership, self-efficacy, and teacher work involvement on organizational citizenship behavior (OCB) in improving teacher work performance. The object of this research is the teacher who teaches at the basic education level of the Abdi Karya Foundation. The study used a survey method by distributing questionnaires. The number of respondents who filled out the questionnaires was 141 teachers, both classroom teachers, and subject teachers, and samples were taken using the Slovin formula from a total population of 146 from all teachers Yayasan Abdi Karya elementary education level. This research was conducted from January 15 to May 15, 2021. The data were analyzed using the SmartPLS (Partial Least Square) analysis application. The results of this study indicate that the servant leadership aspect has a positive and significant effect on organizational citizenship behavior (OCB), self-efficacy has a positive and significant effect on organizational citizenship behavior (OCB), and work engagement has a positive and significant effect on organizational citizenship behavior (OCB), and servant leadership, self-efficacy, and teacher work involvement simultaneously have a positive and significant effect on organizational citizenship behavior (OCB). While organizational citizenship behavior (OCB) has a positive and significant effect on improving teacher work performance.
\end{abstract}

KEYWORDS: Organizational Citizenship Behavior (OCB), Servant Leadership, Self-Efficacy, Work Involvement, Work Performance.

\section{INTRODUCTION}

Education is one of the main pillars in terms of the development and progress of a nation. Quality education can be realized through creative and innovative resources, namely schools. Education is often used as a problem discussed by formal and informal forums, from the ever-changing curriculum, policy basis, management process, and implementers, namely teachers. Teachers as Indonesian human resources are ranked very low among hundreds of countries.

Work performance or teacher performance in educational institutions is very crucial and needs to be improved gradually by looking at the abilities and competencies that the teacher lacks. This work achievement is obtained through observations and monitoring carried out by the principal and must be followed up.

High performance can be seen when teachers have high organizational citizenship behavior (OCB) who can realize educational goals optimally. Organizational citizenship behavior (OCB) is high in teachers, and it is expected that fellow teachers support each other in the process of achieving the goals to be achieved, motivating for student success, achieving learning support school programs, the ability of teachers to establish good relationships with parents in terms of student educational success, and loyalty, against the foundation. For all implementations that support teaching and learning activities in schools, the principal as a leader must ensure that teachers have high-quality standards, expectations, and performance. The principal must have three characteristics: authentic leadership, ethical leadership, and servant leadership. Servant leadership helps teachers become selfserving and display positive organizational behaviors (increasing effectiveness and being proactive about change).

Teachers' ability is often associated with a lack of self-efficacy or self-confidence in their abilities. Self-efficacy or teacher self-confidence plays an important role for teachers in the final success of learning and students. The teacher's work involvement 


\section{International Journal of Current Science Research and Review}

ISSN: 2581-8341

\section{Volume 05 Issue 02 February 2022}

DOI: 10.47191/ijesrr/V5-i2-11, Impact Factor: 5.825

also has a role and concern for work both physically, knowledgeably, and emotionally so that the teacher considers that the work he does is very important and has a strong belief in being able to complete it.

\section{LITERATURE REVIEW}

Servant leadership with vision and commitment is very attractive to the personal development of others. It creates value for the community to provide greater purpose and explanation of each other's roles, ultimately resulting in work and pride for the organization (Coetzer, Geldenhuys and Bussin, 2017). According to Greenleaf in Divya T (2019), servant leadership is someone whose main focus is on the growth and development of employees, through their abilities and potential, the desire to serve others and work for the organization's growth. Servant leadership is expected to positively improve teacher work performance through organizational citizenship behavior (OCB).

H1: The influence of the principal's servant leadership has a positive effect on organizational citizenship behavior (OCB) in improving teacher work performance at the basic education level of Yayasan Abdi Karya.

Bandura (1997) in Arnab Kundu (2020) found that self-efficacy is important because someone with high self-efficacy is more likely to change the work environment and stay in his job when faced with negative outcome expectations. It can be said that the stronger the notion of self-efficacy, the better the effort, persistence, creates a feeling of calm, and gives strength when facing a difficult task. Teacher self-efficacy is one of the central beliefs that influence teacher professional behavior (Durksen, Klassen, \& Daniels, 2017 ) and can positively support improving overall teacher effectiveness (Von Suchodoletz, Jamil, Larsen, \& Hamre, 2018).

$\mathrm{H} 2$ : Teacher self-efficacy has a positive effect on organizational citizenship behavior (OCB) in improving teacher work performance at the basic education level of Yayasan Abdi Karya.

Active employee involvement is needed to provide job satisfaction and motivation according to the employee's expectations increase high morale, and achieve more optimal performance. (Setyo Riyanto, Endri Endri, Novita Herlisha, 2021). Job engagement can be associated with work outcomes such as commitment to their employers, increased job satisfaction, increased work effort, reduced absenteeism, increased organizational citizenship behavior (OCB) beyond what is required in the workplace (Chen and Chiu, 2009; Diefendorff, Brown, 2003). Kamin, and Lord in Youngkeun, Jae Won (2020).According to Schaufeli (2017), work involvement plays an important role and is defined as something positive by fulfilling a psychological state characterized by enthusiasm, dedication, and absorption.

H3: Teacher work involvement has a positive effect on organizational citizenship behavior (OCB) in improving teacher work performance at Yayasan Abdi Karya elementary education level.

Research by Setyo Riyanto, Samrotul Janiah \& Johan Hendri (2021) that discipline is very influential and significant on organizational citizenship behavior and is the best strategy by setting high-performance standards with full responsibility in creating better intra-organizational relationships. Nugroho, Sutjipto, \& Matin (2016) states that teachers who have high organizational citizenship behavior (OCB) usually have loyalty and dedication and carry out work that exceeds their responsibilities. Hamzah \& Lina (2014) suggest that work performance or teacher performance is the interaction between teacher abilities reflected in planning, implementing, and assessing the teaching and learning process whose intensity is based on teacher professionalism's work ethic, and discipline. Endah R and Nur Kholifatul (2018) stated that organizational citizenship behavior (OCB) is not only able to increase job satisfaction, but with increased job satisfaction, employee performance is also getting better.

H4: Principal Servant leadership, teacher self-efficacy, and teacher work involvement together equally affect organizational citizenship behavior (OCB) in improving teacher work performance at the basic education level of Yayasan Abdi Karya.

H5: Organizational citizenship behavior (OCB) has a positive effect on improving teacher performance at the primary education level at Yayasan Abdi Karya.

\section{METHODOLOGY}

\section{A. Research Design}

This study uses a quantitative approach with survey methods and data collection methods in questionnaires. According to Cresweel (2010), the quantitative approach measures quantitative data and objective statistics through scientific calculations derived 


\section{International Journal of Current Science Research and Review}

ISSN: 2581-8341

Volume 05 Issue 02 February 2022

DOI: 10.47191/ijesrr/V5-i2-11, Impact Factor: 5.825

IJCSRR@ 2022

Www.ijcsrr.org

from samples of people or residents who are asked to answer several questions about surveys to determine the frequency and percentage of responses.

\section{B. Operational Definition and Measurement of Variables}

Table 1. Operational Definitions and Research Variables

\begin{tabular}{|c|c|c|}
\hline Variable & Dimension & Indicator \\
\hline \multirow{13}{*}{$\begin{array}{l}\text { Hamzah } \\
\text { B.Uno dan } \\
\text { Nina } \\
\text { Lamatengg } \\
\text { o (2014) }\end{array}$} & \multirow[t]{3}{*}{ 1. Work Quality } & 1. Mastering learning materials \\
\hline & & 2. Managing the teaching and learning process \\
\hline & & 3. Manage Class \\
\hline & \multirow{3}{*}{$\begin{array}{l}\text { 2. Accuracy / } \\
\text { working speed }\end{array}$} & 1. Using media or learning resources \\
\hline & & 2. Mastering the educational foundation \\
\hline & & 3. Planning a teaching program \\
\hline & \multirow[t]{3}{*}{ 3. Initiatives in Work } & 1. Lead the class \\
\hline & & 2. Manage learning interactions \\
\hline & & 3. Assessing student learning outcomes \\
\hline & \multirow[t]{2}{*}{ 4. Ability Work } & 1. Using various methods in learning. \\
\hline & & 2. Understand and carry out the functions and services of counseling guidance \\
\hline & \multirow[t]{2}{*}{ 5. Communicating work } & 1. Understand and carry out school administration \\
\hline & & 2. Understand and interpret research results to improve the quality of learning. \\
\hline \multirow{9}{*}{$\begin{array}{l}\text { Organizati } \\
\text { onal } \\
\text { Citizenship } \\
\text { Behavior } \\
\text { (OCB), } \\
\text { Organ } \\
\text { (2006) } \\
\text { (Mira et al. } \\
2017)\end{array}$} & \multirow[t]{2}{*}{ 1. Altruism } & 1. Help other people whose work is overloaded. \\
\hline & & 2. Volunteer to do something without being asked. \\
\hline & \multirow[t]{2}{*}{ 2. Conscientiousness } & 1. Arrive early, so be ready to work when the work schedule starts. \\
\hline & & $\begin{array}{l}\text { 2. Work because of his consciousness, even though it is not a duty and } \\
\text { authority, and can encourage effectiveness in work }\end{array}$ \\
\hline & 3. Sportsmanship, & Do not exaggerate the problem out of proportion. \\
\hline & \multirow[t]{2}{*}{ 4. Courtesy } & 1. Keeping up with changes and developments in the organization. \\
\hline & & $\begin{array}{l}\text { 2. Always provide knowledge and skills for the sake of achieving the target } \\
\text { that has been set }\end{array}$ \\
\hline & \multirow[t]{2}{*}{ 5. Civic virtue } & 1. Pay attention to functions that help the organization's image \\
\hline & & 2. Pay attention to meetings that are considered important. \\
\hline \multirow{10}{*}{$\begin{array}{l}\text { Servant } \\
\text { leadership } \\
\text { Liden et al. } \\
(2008)\end{array}$} & \multirow[t]{2}{*}{ 1. Emotional healing } & 1. Takes time to talk with subordinates on a personal/private level \\
\hline & & 2. Always provide a sense of comfort when discussing any problems \\
\hline & $\begin{array}{l}\text { 2. Creating value for the } \\
\text { community }\end{array}$ & Leaders emphasize the importance of giving something of value to society \\
\hline & \multirow[t]{2}{*}{ 3. Conceptual skills } & 1. Able to think to solve complex problems innovatively \\
\hline & & $\begin{array}{l}\text { 2. Provide direction and motivation to encourage teachers to do and complete } \\
\text { all tasks and work }\end{array}$ \\
\hline & 4. Empowering & $\begin{array}{l}\text { The leader gives his subordinates the responsibility to make important } \\
\text { decisions about the teacher's work }\end{array}$ \\
\hline & \multirow[t]{2}{*}{$\begin{array}{l}\text { 5. Helping subordinates grow } \\
\text { and succeed }\end{array}$} & $\begin{array}{l}\text { 1. Provide subordinates with new possible work experiences develop new } \\
\text { skills }\end{array}$ \\
\hline & & 2. Always give advice which is very important for my self-development \\
\hline & \multirow[t]{2}{*}{ 6. Putting subordinates first } & 1. Prioritizing the interests of subordinates above their interests \\
\hline & & 2. Understand the desires of subordinates \\
\hline
\end{tabular}




\section{International Journal of Current Science Research and Review}

ISSN: 2581-8341

Volume 05 Issue 02 February 2022

DOI: 10.47191/ijesrr/V5-i2-11, Impact Factor: 5.825

IJCSRR@ 2022

Www.ijcsrr.org

\begin{tabular}{|c|c|c|}
\hline & 7. Behaving ethically & $\begin{array}{l}\text { Treating teachers as individuals whom each have different needs, abilities, } \\
\text { and aspirations }\end{array}$ \\
\hline \multirow{6}{*}{$\begin{array}{l}\text { Efikasi Diri } \\
\text { Bandura } \\
(2009)\end{array}$} & \multirow[t]{2}{*}{ 1. Magnitude } & $\begin{array}{l}\text { 1. Enthusiastic in work and avoid situations and behavior beyond the limits of } \\
\text { ability }\end{array}$ \\
\hline & & 2. Strive to achieve reasonable work results by completing tasks at work \\
\hline & \multirow[t]{2}{*}{ 2. Strength } & 1. Confidence in the success of what is done. \\
\hline & & 2. Find solutions when experiencing obstacles at work \\
\hline & \multirow[t]{2}{*}{ 3. Generality } & 1. Beliefs that spread across various areas of behavior \\
\hline & & 2. Dig up information about how to work well \\
\hline \multirow{6}{*}{$\begin{array}{l}\text { Keterlibata } \\
\mathrm{n} \quad \text { Kerja } \\
\text { Robbin and } \\
\text { Judge } \\
(2013)\end{array}$} & \multirow{2}{*}{$\begin{array}{l}\text { 1. Actively participate in } \\
\text { profession }\end{array}$} & 1. Always devote attention and work time \\
\hline & & 2. Most goals in life are work-oriented \\
\hline & \multirow{2}{*}{$\begin{array}{l}\text { 2. Show work as the main } \\
\text { thing }\end{array}$} & 1. Work is something that comes first \\
\hline & & 2. Trying to meet the work targets that have been determined \\
\hline & \multirow{2}{*}{$\begin{array}{l}\text { 3. Sees his work as something } \\
\text { important to pride }\end{array}$} & 1. Feeling worthy, if it produces good work \\
\hline & & 2. Work that is occupied following the principles of life and full of confidence \\
\hline
\end{tabular}

\section{Population and Sample}

The population in this study were all teachers at the basic education level of Yayasan Abdi Karya with a total of 146 people, and the sample used was the entire population.

\section{Data Analysis}

The data were analyzed using the SmartPLS (Partial Least Square) analysis application for the instrument test, namely the validity test with convergent validity (said valid if the value> 0.70) and reliability test with Cronbach Alpha (if the Cronbach Alpha value $>0.60$ ). Furthermore, to test the variables, namely the Outer Model and Inner Model (test the model's accuracy and hypothesis).

\section{RESULTS AND DISCUSSION}

The results obtained regarding the general description of research respondents based on: a) class teacher positions (16\%) and subject teachers $(84 \%)$; b) the employment status of foundation permanent teachers (48\%) and non-permanent foundation teachers $(52 \%)$; c) age $\leq 25$ years (13\%), 25.1-35 years (36\%), 35.1-45 years (21\%), $45.1-55$ years $(21 \%)$ and above 55 years (9\%); d) length of work $\leq 5$ years (36\%), 5.1-10 years $(15 \%), 10.1-15$ years $(20 \%), 15.1-20$ years $(12 \%),>20.1$ years $(17 \%)$; e) gender male $(31 \%)$, female $(69 \%) ; \mathrm{f})$ the last education is diploma $3(1 \%)$, strata $1(89 \%)$ and strata $2(10 \%)$.

The results regarding the description of variables with average values are servant leadership $(4,173)$, self-efficacy $(4,128)$, work involvement (4,031), organizational citizenship behavior (4,088), and work performance $(4,231)$. The results of the survey data analysis were then tested for validity and reliability; The test result is that all the questions in the questionnaire are valid and reliable.

Table 2. Average Variance Extracted (AVE) Test Results

\begin{tabular}{|l|l|l|l|}
\hline Variable & $\begin{array}{l}\text { Average Variance } \\
\text { Extracted (AVE) }\end{array}$ & Term & Description \\
\hline Servant Leadership & 0.590 & $>0,5$ & Valid \\
\hline Self Efficacy & 0.637 & $>0,5$ & Valid \\
\hline Work Involvement & 0.666 & $>0,5$ & Valid \\
\hline Work Performance & 0.590 & $>0,5$ & Valid \\
\hline $\begin{array}{l}\text { Organizational Citizenship } \\
\text { Behavior }(O C B)\end{array}$ & 0.627 & $>0,5$ & Valid \\
\hline
\end{tabular}

Source: Questionnaire Testing Data Processing Results with SmartPLS version 3.0,2021 


\section{International Journal of Current Science Research and Review}

ISSN: 2581-8341

\section{Volume 05 Issue 02 February 2022}

DOI: 10.47191/ijcsrr/V5-i2-11, Impact Factor: 5.825

IJCSRR@ 2022

Table 3. Composite Reliability Test Results

\begin{tabular}{|l|l|l|l|}
\hline Variable & $\begin{array}{l}\text { Composite } \\
\text { Reliability }\end{array}$ & Term & Description \\
\hline Servant Leadership & 0.940 & $>0,7$ & Reliable \\
\hline Self Efficacy & 0.913 & $>0,7$ & Reliable \\
\hline Work Involvement & 0.923 & $>0,7$ & Reliable \\
\hline Work Performance & 0.949 & $>0,7$ & Reliable \\
\hline Organizational Citizenship Behavior $($ OCB) & 0.938 & $>0,7$ & Reliable \\
\hline
\end{tabular}

Source: Questionnaire Testing Data Processing Results with SmartPLS version 3.0,2021

Table 4. Cronbach's Alpha. Test Results

\begin{tabular}{|l|l|l|l|}
\hline Variable & $\begin{array}{l}\text { Cronbach's } \\
\text { Alpha }\end{array}$ & Term & Description \\
\hline Servant Leadership & 0.931 & $>0,7$ & Reliable \\
\hline Self Efficacy & 0.889 & $>0,7$ & Reliable \\
\hline Work Involvement & 0.900 & $>0,7$ & Reliable \\
\hline Work Performance & 0.942 & $>0,7$ & Reliable \\
\hline Organizational Citizenship Behavior $(O C B)$ & 0.926 & $>0,7$ & Reliable \\
\hline
\end{tabular}

Source: Questionnaire Testing Data Processing Results with SmartPLS version 3.0,2021

Table 5. Hypothesis Testing

\begin{tabular}{|l|l|l|l|l|l|}
\hline Variabel & $\begin{array}{l}\text { Original } \\
\text { Sample }(\mathbf{O})\end{array}$ & $\begin{array}{l}\text { Sample } \\
\text { Mean (M) }\end{array}$ & $\begin{array}{l}\text { Standard } \\
\text { Deviation } \\
\text { (STDEV) }\end{array}$ & $\begin{array}{l}\text { T Statistics } \\
\text { (|O/STDEV|) }\end{array}$ & P Values \\
\hline Servant Leadership $->O C B$ & 0.289 & 0.298 & 0.067 & 4.299 & 0.000 \\
\hline Self Efficacy -> $O C B$ & 0.363 & 0.364 & 0.073 & 4.992 & 0.000 \\
\hline Work Imvolvement -> $O C B$ & 0.207 & 0.215 & 0.066 & 3.163 & 0.002 \\
\hline$O C B$-> Prestasi Kerja & 0.389 & 0.404 & 0.080 & 4.886 & 0.000 \\
\hline
\end{tabular}

Source: Questionnaire Testing Data Processing Results with SmartPLS version 3.0,2021

Based on table 5, it can be concluded that the results of testing the direct influence hypothesis are as follows:

1) Hypothesis 1: Servant leadership on organizational citizenship behavior (OCB)

Servant leadership has a t-statistic value of $4.299>1.96$, p-value $0.000<0.05$ and original sample 0.289 , so H1 is accepted, meaning that servant leadership has a positive and significant effect on organizational citizenship behavior (OCB).

2) Hypothesis 2: Self-efficacy on organizational citizenship behavior (OCB)

Self-efficacy has a t-statistic value of $4.992>1.96$, p-value $0.000<0.05$ and original sample 0.363 then $\mathrm{H} 2$ is accepted, meaning that self-efficacy has a positive and significant effect on organizational citizenship behavior (OCB).

3) Hypothesis 3: Work involvement on organizational citizenship behavior (OCB)

Work involvement has a t-statistic value of $3.163>1.96$, p-value $0.002<0.05$ and original sample 0.207 , so H3 is accepted, meaning that work involvement has a positive and significant effect on organizational citizenship behavior (OCB).

4) Hypothesis 5: Organizational citizenship behavior (OCB) on job performance

Organizational citizenship behavior (OCB) has a t-statistic value $4.886>1.96$, p-value $0.018<0.05$ and original sample 0.389 then $\mathrm{H} 5$ accepted, it means that organizational citizenship behavior (OCB) has an effect positive and significant to work performance. 


\section{International Journal of Current Science Research and Review}

ISSN: 2581-8341

\section{Volume 05 Issue 02 February 2022}

DOI: 10.47191/ijcsrr/V5-i2-11, Impact Factor: 5.825

IJCSRR@ 2022

For Hypothesis 4, namely servant leadership of school principals, teacher self-efficacy and teacher work involvement together affect organizational citizenship behavior (OCB) in improving teacher work performance at the basic education level of Yayasan Abdi Karya, tested using the following formula:

$$
\begin{gathered}
\frac{R^{2}(n-k-1)}{\left(1-R^{2}\right) k} \\
\text { Fhit }=\frac{0.356(141-3-1)}{(1-0.356) 3} \\
\text { Fhit }=\frac{48.81}{1.93}=25.273
\end{gathered}
$$

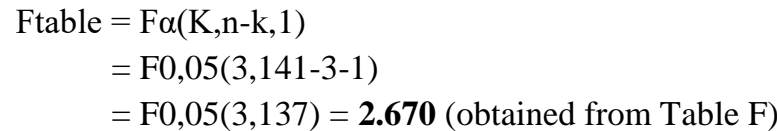

Simultaneous significant test results can be seen in the calculation results. The F test was conducted to determine the effect of the variable servant leadership, teacher self-efficacy, and teacher work involvement together on organizational citizenship behavior (OCB). For testing with the F test is to compare the value of Ftable with Fcount. The value of Fcount is 25.273, Ftable is 2.670 (see Table F), thus the F arithmetic result (25.273) > F table (2.670) then H4 is accepted. The results obtained show that the variables of principal servant leadership, teacher self-efficacy, and teacher work involvement together affect organizational citizenship behavior (OCB) in improving teacher work performance at the basic education level at Yayasan Abdi Karya.

\section{CONCLUSION}

The conclusions of the results of this study are as follows:

1. The servant leadership aspect of the principal has a positive and significant effect on the principal on organizational citizenship behavior (OCB), which means that the better the value of the servant leadership of the principal in giving responsibility to teachers in making decisions in carrying out their main tasks, the better the value of organizational citizenship behavior (OCB). Moreover, what still needs to be improved is the ability of the principal as a leader to think in solving complex problems in an innovative way.

2. The aspect of self-efficacy has a positive and significant effect on organizational citizenship behavior (OCB), which means the better the teacher's self-efficacy value, especially in the spirit of working, and doing work without supervision from superiors, the better the value of organizational citizenship behavior (OCB). Moreover, what still needs to be improved is the teacher's selfefficacy for success in the tasks assigned to him by his superiors.

3. Aspects of teacher work involvement have a positive and significant impact on organizational citizenship behavior (OCB), which means the better the value of teacher work involvement, especially in their efforts to meet the given target and consider it something important, the better the value of organizational citizenship behavior (OCB). . And what still needs to be improved is the teacher always to devote attention and time to work.

4. Aspects of servant leadership, teacher self-efficacy, and work involvement simultaneously on organizational citizenship behavior (OCB). Combining servant leadership variables, teacher self-efficacy, and work involvement will significantly influence organizational citizenship behavior (OCB).

5. Aspects of organizational citizenship behavior (OCB) on work performance, which means the better the value of organizational citizenship behavior (OCB), especially the willingness of teachers to follow changes and developments in the proper organization at work, the better the teacher's work performance will be. Moreover, the thing that still really needs to be reminded is the teacher's motivation in helping other people whose work is overloaded.

\section{REFERENCES}

1. Arnab Kundu. (2020). Toward a Framework for Strengthening Participants. Self-efficacy in Online Education. Department of Education, Bankura University, Bankura, India. https://doi.org/10.1108/AAOUJ-06-2020-003

2. Bandura, A. (2009). Cultivate Self-Efficacy for Personal and Organizational Effectiveness. Di dalam Locke E.A. (Ed). (pp. 179-200). Handbook of Principles of Organization Behavior. (2nd Ed.). New York: Wiley

3. Creswell, J. W. (2010). Research Design: Pendekatan Kualitatif, Kuantitatif, dan Mixed. Yogjakarta: PT Pustaka Pelajar. 


\section{International Journal of Current Science Research and Review}

ISSN: 2581-8341

Volume 05 Issue 02 February 2022

DOI: 10.47191/ijesrr/V5-i2-11, Impact Factor: 5.825

IJCSRR@ 2022

www.ijcsrr.org

4. Divya Tripathi (2019). Does Servant Leadership Affect Work Role Performance via Knowledge Sharing and Psychological Empowerment?. Journal of Information and Knowledge Management Systems. https://doi.org/10.1108/VJIKMS-10-2019$\underline{0159}$

5. Durksen, Klassen, \& Daniels (2017). Motivation and Collaboration: The Keys to a Developmental Framework for Teachers' Professional Learning. https://doi.org/10.1016/j.tate.2017.05.011.

6. Endah R, Nur Kholifatul (2018). Pengaruh Organizational Citizenship Behavior (OCB) terhadap Kepuasan Kerja dan Kinerja Karyawan. Industria : Jurnal Teknologi dan Manajemen Agroindustri Vol. 7 No.2. Universitas Brawijaya, Malang.

7. Hamzah B.Uno dan Nina Lamatenggo. (2014). Teori Kinerja dan Pengukurannya. Jakarta. Bumi Aksara.

8. Liden, R. C., Wayne, S. J., Zhao, H., \& Henderson, D. (2008). Servant leadership: Development of Multidimensional Measure and Multilevel Assessment. The Leadership Quarterly, 19, 161-177.

9. Michael F. Coetzer, Madelyn Geldenhuys and Mark H.R.Bussin (2017). The Function of Servant Leader. Economics; Administrative Sciences. February, 2017. https://doi.org/10.3390/admsci7010005

10. 10.Mira Ariyani, Desty Zulkarnain. (2017). Organisational Citizenship Behaviour (OCB) pada Guru Ditinjau Dari Faktor Demografi. Fakultas Pendidikan Psikologi, Universitas Negeri Jakarta. DOI: https://doi.org/10.21009/JPPP.062.03

11. Nugroho, D. S., Sutjipto, dan Matin. (2016). Hubungan Antara Kepuasan Kerja dengan Perilaku Kewargaorganisasian (PKO) Guru di SMK Negeri Kecamatan Pasar Minggu Kota Administrasi Jakarta Selatan. Improvement, 3, 54-63.

12. Robbins, Stephen P \& Judge, Timothy A. (2013). Organizational Behavior Edition 15. New Jersey: Pearson Education

13. Schaufeli, W. B. (2017). Applying the Job Demands-Resources Model: A 'How to' Guide to Measuring and Tackling Work Engagement and Burnout. Organizational Dynamics, 120-132.

14. Setyo Riyanto, Samrotul Janiah, Johan Hendri Prasetyo. 2021.Academy of Strategic Management Journal Research Article: 2021 Vol: 20 Issue: 3

15. Setyo Riyanto, Endri Endri and Novita Herlisha (2021). Effect of Work Motivation and Job Satisfaction on Employee Performance: Mediating Role of Employee Engagement. Problems and Perspectives in Management, 19(3), 162-174. https://doi.org/10.21511/ppm.19(3).2021.14

16. Von Suchodoletz, Jamil, Larsen, \& Hamre. (2018). Personal and Contextual Factors Associated With Growth in Preschool Teachers' Self-efficacy Beliefs during a Longitudinal Professional Development Study.

https://doi.org/10.1016/j.tate.2018.07.009

17. Youngkeun Choi. (2020). Sangmyung University, Jongno-gu, Republic of Korea, and Jae Won Choi. 2020. Erik Jonsson School of Engineering and Computer Science, The University of Texas at Dallas, Richardson, Texas, USA. https://doi.org/10.1108/IJOA-05-2020-2222

Cite this Article: Meilani, Setyo Riyanto (2022). The Influence of Principal Servant Leadership, Self-Efficacy and Teacher Work Involvement on Organizational Citizenship Behavior (OCB) in Improving Teacher Work Performance at the Yayasan Abdi Karya Elementary Education Level. International Journal of Current Science Research and Review, 5(2), 383-389 